\title{
Entrepreneurial Potentials of Insect Farming in Nigeria
}

\author{
O. S. Ibitoye* O. S.Kolejo P. O. Oyetunji \\ Onigambari Research Station, Forestry Research Institute of Nigeria
}

\begin{abstract}
Insects provide a wild variety of uses and benefits ranging from Agriculture to medicine, industries and research. They have been reared for food, feed, silk production and dye making. Recently, a lot attention has been drawn worldwide to the usefulness of insect in the food and feed industry because of their high nutrition contents and environmental sustainability. For these reasons, a lot of insect based entrepreneurs have sprung up in Africa in response to this development, but in Nigeria only few entrepreneurs are interested in engaging in insect farming due to information gap. This research aims to bridge the gap by identifying species of insects that can be farmed, for what purpose they are farmed, potentials embedded in insect product development, and factors affecting edible insect entrepreneurs in Nigeria. Data were sourced by querying many research databases outlets such as science direct, researchgates, google scholar, Ajol and so on. This research identifies palm weevil, crickets, grasshopper and pallid emperor moth as insect that can be farmed with high demand as food in Nigeria. The maggot of housefly and Black soldier fly are recommended for animal feed and silk warm for textile industry. The review recommends that the government should encourage insect entrepreneurs in Nigeria through training and improve extension services.
\end{abstract}

Keywords: Agribusiness; Entomophagy; Insects farming systems; Insect value chain.

DOI: $10.7176 /$ JNSR/9-9-07

Publication date:May $31^{\text {st }} 2019$

\section{Introduction}

Nigeria is the most populous nation in Africa with majority of its population within the working age group, By 2050 , it is projected to have $433 \mathrm{~m}$ people, more than the US, and behind only India and China (Jakob, 2012). The country is endowed with a lot of natural resources, such as agriculture, having $70 \%$ of its land as arable land. Forest resources are abounding with enriching forest products yet to be tapped. Despite this, Nigeria is still a mono-product economy heavily dependent on crude oil for more than $90 \%$ of its foreign exchange earnings (Metu and Nwokoye, 2014). Consequently, majority of its population is extremely poor, "with over $50 \%$ of its population depending on US\$ 1 per day for livelihood; the poverty rate witnessed in recent years exceeded the first oil boom recorded in 1970s, which was 35\%" (Mähler, 2010). Unemployment rate in Nigeria is alarming (Ihugba et al, 2013) and government has done little to reduce the misery and frustration to its teaming youth. In order to address this problems of high unemployment rate and endemic poverty, there is need for maximum utilization of the natural resources to foster development through entrepreneurship. Tapping the country's resources require the ability to identify potentially useful, economically viable and developmental enterprise in the country.

Insect being a candidate of the aforementioned listed properties, is blessed with a lot of untapped resources. Insect is tipped worldwide has a recognized food (Tiencheu and Womeni, 2017; Van Huis et al, 2013;Van Huis, 2015; Dobermann et al, 2017), But here in Africa, insect eating has been part of our menu for centuries (Van Huis, 2003; Adeoye et al,2014; Ebenebe and Okpoko, 2015), also insect is used has feed formulation for domestic animals (Kenis, et al., 2014); (Karigidi, 2018) and pets (Bosc et al, 2014). The sudden awareness generated by insect as food is due to its nutritional benefit (Khalaf and Elansary, 2018)and environmental qualities (Huis and Oonincx, 2017). There are increasing needs of animal protein in Nigeria, According to (Ebenebe, 2005) the current protein consumption level is 7-10 g/person/day. This do not meet the standard set by the Food and Agriculture Organization of the United Nations of $34 \mathrm{~g}$ of animal protein consumption per person per day.

The protein content of edible insect has been proven to be higher than other animals and plant food such as Beef, chicken, fish, Soybeans and maize (Alamu et al, 2013). Insects are also rich in essential vitamins such as phosphorus, magnesium, zinc, calcium and iron and in nutrients such as amino acids, which are often absent in conventional foods (Banjo et al, 2006). Aside the nutritional qualities of edible insects, it is said to be more environmentally friendly than other livestock. They utilize less land and water, emit lower green house emissions, they don't waste food because of their high feed conversion rate, they turn organic waste of low value to products of high value and insect is often used to replace fishmeal which is scarce and highly expensive (Huis and Oonincx, 2017). Engaging in edible insect enterprise helps to meet Sustainable Development Goal (SDG) two of the United Nations which is to achieve food security and improve nutrition (hunger reduction) (Dicke, 2018). Also SDG thirteen talks about taking urgent actions against climate change and its impacts in which insect fit perfectly to this profile as they are more environmentally friendly and more sustainable than their direct alternatives.

Nigeria is blessed with diversity of these insects, almost every ecological zone and geopolitical zone has them in abundance. Insects are useful as food for humans, animals' feed, clothe production (Silk) and in making drugs 
locally. Potentials embedded along its value chain are enormous. There are ready made markets for insect and insect products nationwide and internationally, but poor information of its value and usage has made entrepreneurs not to venture into it. People still have the notion of the difficulties of having to harvest them from the wild, which is tasking and many times not financially rewarding. Furthermore, seasonal fluctuations affects availability of insects from the wild. Recently, commercial and intentional farming of insect for profit is now the practice worldwide. Products such has silk clothes, honey bee production, cricket biscuit, cricket flour, Bayelsa suya e.t.c.can be targeted by entrepreneurs to make viable entrepreneurial ventures that can reduce unemployment, poverty while creating sources of income which will raise the standard of living. This research attempts to identify insect diversity in Nigeria for food and feed, products that can be gotten from insect commonly seen in Nigeria, explain method of farming of some selected insect in Nigeria and discuss the insect value chain present in Nigeria.

\section{Methodology}

Search were made on keywords like "edible insect farming", "edible Insect products", "edible insects and entrepreneur" these were mostly centered on research outcomes worldwide. The search was done on "Google Scholar", "PubMed", "Science-Direct", "Scopus"and "Web of Science"databases. Many journals' sites were queried for information on edible insect and their potential uses. Springer, Elsevier, Ajol and dissertation search engines like Open-thesis, OATD, ProQuest and EthOs were put to use. Also information were utilized from Authors experience through observations and interacting with stakeholders in edible insect Industry.

\section{Results and Discussion}

Insect stages of Entrepreneurial Engagement

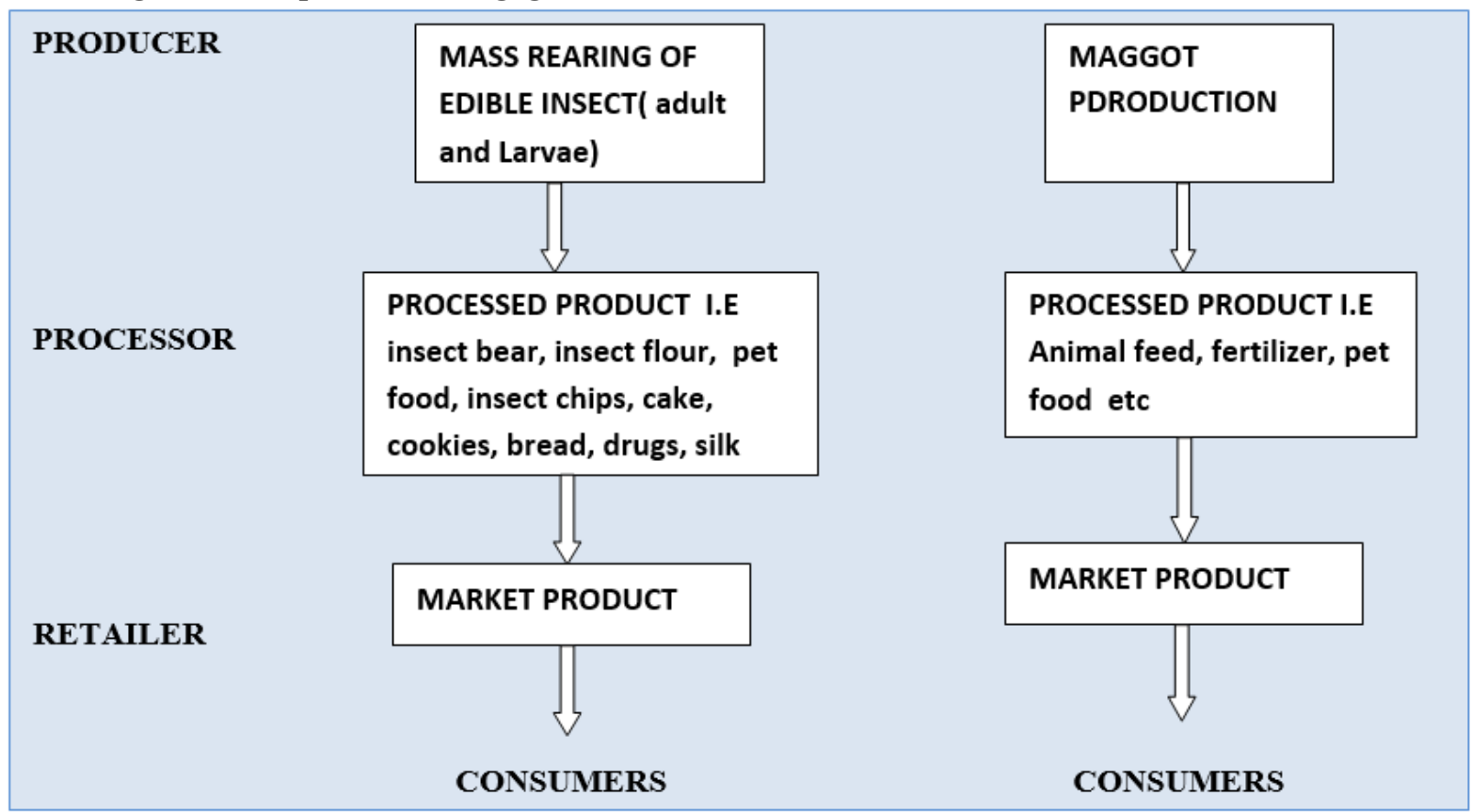

Figure 1: showing stages of Entrepreneurial involvements of edible insects

Edible insect is tipped worldwide as a product with potentials as human food, animal feed and industries. The entrepreneurial potential is enormous ranging from production to processing. Before it gets to its final consumers (fig. 1), entrepreneurs may decide to stay at the any stage of entrepreneur engagement. Those interested in alone production level alone may maintain this level so far there is ready market for its products. Likewise entrepreneurs may occupy the position of a processor leveraging on what the producers produce. Business owners could stay along the value chain of retailing the products to the consumer. All through edible insect value chain are hidden employment opportunities especially for youths in developing countries.

\section{Entrepreneurial potentials of farming Insects for food}

Edible insects fed upon by Nigerians are usually collected from the wild, this are mostly affected by seasonality, quality time wastage during harvesting, little quantity collected. Subsequently, because of its scarcity there will be breakage in the supply of edible insect hence high pricing. In Nigeria especially in rural area which are closer to the wild, insect farming will facilitate food provision particularly against food shortage due to seasonal drought in production; it provides additional cash for basic expenditures including food, farm implements and education. Insect farming for food also provide opportunities for improvement of local diets, employment, Health and earning 
income to landless dwellers and women who are involved in the gathering, farming/cultivation, processing, and sale of insects (Gahukar, 2016). Edible insects are found in all ecological zones of Nigeria in with each geopolitical zones have different potential edible insect to be farmed for profit( table 1). (Alamu et al, 2013) reported a list of 22 most consumed insect in Nigeria distributed according to their order, $77.3 \%$ were Lepidoptera (27.3\%), Coleoptera (27.3\%), Orthoptera (22.7\%) and 22.7\% Isoptera, Hemiptera and Hymenoptera. This shows that edible insect consumed in Nigeria are spread across many orders (Figure 2). Out of this vast numbers of insect consumed, only a few number of them are farmed in Nigeria and those farmed are not in commercial quantity.

Palm weevils, Rhynchophorus spp, are excellent low cost sources of essential nutrients. They are highly delicious and are commonly prepared roasted, they have low carbon footprint if farmed as a commercial enterprise. Palm weevils serve as a traditional meal for natives of most rural societies (especially within the southern part of the country) but are not farmed for consumption rather harvested from the wild. (Muafor et al. 2015. ) reported indigenous method of palm weevil farming, The traditional grub gathering and grub semi-farming. These systems of farming represent 30 to $75 \%$ of the household income in the study area.(Ebenebe \& Okpoko, 2016) reported 8 different culturing substrates for rearing Palm weevil (coconut fiber, coconut fiber with palm wine, sawdust of mahogany, sawdust of mahogany with palm wine, palm frond petiole, palm bunch midrib, sugarcane tops (SCT), spoilt watermelon (SWM)). The result revealed that the larva thrived better in spoilt water melon and sugarcane top but failed to pupate in SWM. Mass production can be tried with spoil water melon since it will be cheaper and it will help in waste recycling. Palm weevil farming is a cost-effective enterprise in terms of supplies and labour. The larvae reaches maturity within three to four months and can be harvested for consumption - very rich in protein.

Cirina forda is a delicacy eating mostly by people from the southern part of Nigeria (Table 1), it is significantly rich in protein, fat and essential minerals. Producing it for food will be good for business since there is currently no commercial farm producing this delicious protein source. A Large number of the insect is gathered from the wild before processed to be sold in major markets in southwestern part of Nigeria. (Ande and Fasoranti, 1998) reported that Larvae of Cirina forda can be raised on leave of a growing Vittelaria paradoxa tree, all instars developed and harvested within one month. Decades after this discovery, the larvae have not been commercially produce despite the enormous potential hidden in it. Embarking on this enterprise is a potentially lucrative business.(Ebenebe and Okpoko, 2015)reported that cricket (Gymnogryllus lucens) was the most preferred insect to consume in Nigeria, but it is onlycapturedin the wild in Nigeria. Reports of its domestication has been documented globally (Miech et al,2016;Ayieko et al, 2016; Halloran et al, 2016). Ability to get requisite skills and access to training and information by potential entrepreneurs maybe some of the reasons why most of these insects are not farmed in commercial quantities in Nigeria. Grasshopper species such as Nomadacris spp., Kraussaria spp. Ornithacris spp. Zonozerus spp are collected for consumption majorly in the northern part of Nigeria (Sharah, 2013),(Ghosh,et al, 2014)mass rearing of grasshopper will be a lucrative and rewarding idea.

Table 1: Ecological Distributionof commonly eaten insect in Nigeria

\begin{tabular}{|c|c|c|}
\hline $\begin{array}{l}\text { Ecological } \\
\text { zone }\end{array}$ & $\begin{array}{l}\text { Geopolitical } \\
\text { Zone }\end{array}$ & Insects \\
\hline $\begin{array}{l}\overline{\text { Sahel }} \\
\text { Savannah }\end{array}$ & $\overline{\text { North East }}$ & $\begin{array}{l}\text { Grasshopper, Locust, Cricket, Pallid emperor moth larva, Emperor moth } \\
\text { (Adeoye et al, 2014); } \\
\text { (Amobi and Ebenebe, 2018). }\end{array}$ \\
\hline $\begin{array}{l}\text { Sudan } \\
\text { savannah }\end{array}$ & North West & $\begin{array}{l}\text { Grasshopper, Locust, Cricket and Emperor moth (Adeoye et al, 2014) } \\
\text { (Amobi and Ebenebe, 2018) }\end{array}$ \\
\hline $\begin{array}{l}\text { Northern } \\
\text { Guinea } \\
\text { Savannah }\end{array}$ & $\begin{array}{l}\text { North } \\
\text { Central }\end{array}$ & $\begin{array}{l}\text { Grasshopper, Locust and Cricket, Pallid emperor moth larva, Emperor moth, } \\
\text { Mole Cricket, Green Stink Bug, Termites (Macrotermes } \\
\text { Rhinoceros beetle, Bunea alcine Cram (Amobi and Ebenebe, 2018; Adeoye } \\
\text { et al, 2014; Agbidye and Nongo, 2009; Meludu and Onoja, 2018) }\end{array}$ \\
\hline $\begin{array}{l}\text { Derived } \\
\text { savannah }\end{array}$ & South East & $\begin{array}{l}\text { Winged termite, Raffia palm grub/ African Palm weevil, House cricket, Mole } \\
\text { cricket, Termite, Grasshopper, Locust, Caterpillar of Butterfly and Moth, Yam } \\
\text { beetle, Praying mantis, Rhinoceros beetle, Greenish beetle, two unidentified } \\
\text { species (Ebenebe et al, 2017) }\end{array}$ \\
\hline \multirow[t]{2}{*}{$\begin{array}{l}\text { Humid } \\
\text { Forest }\end{array}$} & South West & $\begin{array}{l}\text { Raffia palm grub/ African Palm weevil, Snout beetle,Pallid emperor Moth } \\
\text { (Cirina forda), Rhinoceros beetle, local silkworm (Anaphae } \\
\text { venata),Analeptes trifasciata, Yam beetle, Grasshopper, Honey bee, Termite } \\
\text { ( } 3 \text { species: Macrotermes nigeriensis, Macrotermes bellicosis and), Cricket ( } \\
\text { species: Brachytrupes membranaceus and Gymnogryllus lucens), Mole } \\
\text { cricket (Adeoye et al, 2014; Banjo,2006). }\end{array}$ \\
\hline & Niger Delta & $\begin{array}{l}\text { Termite, Crickets, Locust, Grasshopper, African Palm weevil, Rhinocerus } \\
\text { beetle, Praying mantis, Yam beetle, Rice weevil, Bean beetle, Egg fruit borers, } \\
\text { Mopane worms, Bees, House fly, Cotton stainer, Aphids (Okore et al,2014) }\end{array}$ \\
\hline
\end{tabular}




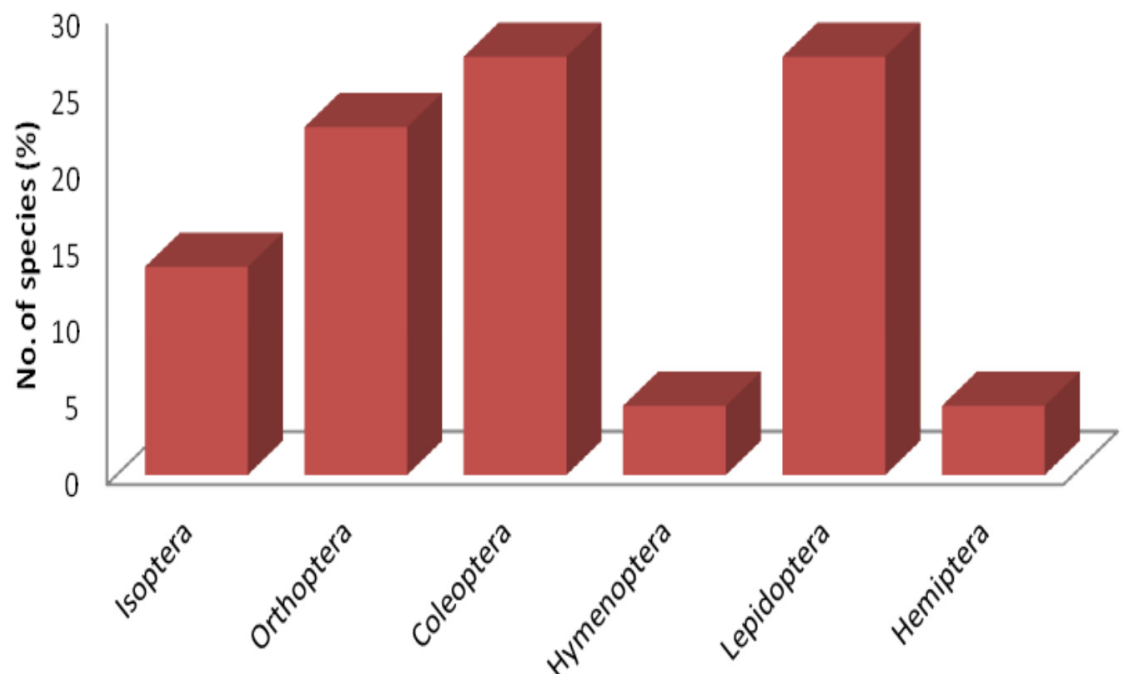

Figure 2. The percentage of insect species per order eaten in Nigeria. (Source: (Alamu, Amao, Nwokedi, Oke, \& Lawa, 2013)

\section{Entrepreneurial potentials of farming Insect for feed}

Almost $60-70 \%$ increase in consumption of animal protein is predicted by 2050 to meet up with the population demands. This increase will require enormous resources, feed being the most demanding due to the scarcity of natural resources and climate change. The cost of the usual animal feed are very high and their sustainability is queried. Insect rearing could play a part in the solution. Many insects have being tried as a major ingredients in the diets of some animal species (Table: 2). The once that shows potential out of these insects areflies, especially the house fly (Musca domestica) (Diptera Muscidae)and the black soldier fly (Hermetia illucens) (Diptera Stratiomyiidae), which can be mass reared on-farm for domestic use, in small production units at the community or industrial level (Kenis et al, 2014). This is so because of its prevalence in most habitats, its fast development, and the possibility of obtaining high numbers of maggots and pupae naturally on various substrates without having to rear adults for egg laying. A South Africa company named Agriprotein is producing billions of maggot, this maggot are fed organic waste manure - producing a nutrient-rich fertilizer in the process - before being harvested and dried into a natural and sustainable animal feed. Agriprotein's maggot-based animal feed is estimated to be $15 \%$ cheaper than conventional feeds and has been proven to have higher nutritional values for livestocks. It's no shocker that the company recently won more than $\$ 10$ million in capital to build more fly farms in South Africa. Table2: Insect used as Animal feed in Nigeria

\begin{tabular}{|c|c|c|}
\hline Animal type & Insect species & Reference \\
\hline $\begin{array}{l}\text { Nile tilapia (Oreochromis } \\
\text { niloticus) }\end{array}$ & locust (Locusta migratoria) & (Abanikannda, 2012) \\
\hline $\begin{array}{l}\text { African catfish } \\
\text { Clarias gariepinus } \\
\text { (Burchell. } \\
\text { fingerlings }\end{array}$ & $\begin{array}{l}\text { variegated grasshopper (Zonocerus variegates } \\
\text { L.) }\end{array}$ & (Alegbeleye,2012) \\
\hline $\begin{array}{l}\text { African catfish (Clarias } \\
\text { gariepinus) }\end{array}$ & $\begin{array}{l}\text { Musca domestica ( Housefly Lavae) } \\
\text { Maggot meal }\end{array}$ & (Aniebo et al, 2009) \\
\hline $\begin{array}{l}\text { Nile perch, } \\
\text { Oreochromis niloticus }\end{array}$ & $\begin{array}{l}\text { Musca domestica ( Housefly Lavae) } \\
\text { Maggot meal }\end{array}$ & $\begin{array}{l}\text { (Ebenso and Udo, 2003; Ogunji } \\
\text { et al, 2008) }\end{array}$ \\
\hline Broiler- Chicken & $\begin{array}{l}\text { Musca domestica ( Housefly Lavae) } \\
\text { Maggot meal }\end{array}$ & (Awoniyi et al, 2003) \\
\hline Cockerel & $\begin{array}{l}\text { Musca domestica ( Housefly Lavae) } \\
\text { Maggot meal }\end{array}$ & (Bamgbose, 1999) \\
\hline Broiler- Chicken & Grasshopper meals & (Ojewola et al, 2003) \\
\hline Broiler- Chicken & $\begin{array}{l}\text { Black soldier fly larvae meal (Hermetia } \\
\text { illucens) }\end{array}$ & (Oluokun, 2000) \\
\hline Poultry Birds & Cirina forda(westwood) & (Oyegoke et al, 2006) \\
\hline Piggery & $\begin{array}{l}\text { Black soldier fly (Hermetia illucens) } \\
\text { House fly(Musca domestica) and yellow } \\
\text { mealworm (Tenebrio molitor) }\end{array}$ & (Veldkamp and Bosch, 2015) \\
\hline
\end{tabular}




\section{Insect farming for textile and medicines}

Silk worm, Bombyx mori L. (Lepidoptera: Bombicidae) is important and known for producing Mulberry silk. It can be domesticated and rear for silk production which has been exploited for over 4000 years ago. The development of cocoon is highly dependent on the feeding larvae stage whose nutritional appetites is on quality mulberry leaves (Alebiosu et al, 2014). Silk is a natural fiber with a wide market throughout the world. Traditionally, household spinners and weavers produce a variety of beautifully coloured fabrics for both domestic and ceremonial uses by blending different colors (Kanika et al, 2016). China and India are the best silk producing countries. Nigerian entrepreneurs and Africa at large can take a cue from these countries to go into silk production which has been proven to be rewarding due to the worldwide demand for it. Some insects have been identified and reported to be used traditionally as traditional medicine worldwide (Denisha and Rokozeno, 2016; Afam and Netshiheni, October 4th, 2017). Although the potency of some this traditional medicine have not been ascertained, traditional medicine is a huge industry in Africa in which many rural households livelihood depend on.

\section{Edible insect product development}

In addition to farming insects and using them raw as food or feed, opportunities abound in processing them into finished goods. Although in Africa insect eating has long been culturally accepted but in the western world the idea is still new with low acceptability and willingness to eat insect(Francesco et al. 2017; Niels and Lieberoth, 2018). Likewise in some urban areas in Africa, acceptability of edible insect is quite low, maybe due to urbanization, educational level and perception issues. Therefore, some initiatives were innovated to reduce the "disgust factor" out of this insect and make them more appealing to the general populace (Table 3). Entrepreneurs can key into this understanding and engage in edible insect product development that will help to increase the acceptability of edible insect worldwide. Packaging is one of the things entrepreneurs in edible insect industry need to take serious as it is the first thing a consumer sees before selecting the product (Nawaz, 2012).

Table 3:Insect entrepreneurial potential

\begin{tabular}{|c|c|c|c|}
\hline Insect enterprise Name & Insect Product & Product Value addition & Reference \\
\hline \multirow[t]{2}{*}{ Cricket farm } & Cricket flour & $\begin{array}{l}\text { Smoothie, cake, chips, biscuit, } \\
\text { protein shakes, peanut butter, } \\
\text { Cricket paster, cookes }\end{array}$ & (James and Ketty, 2018) \\
\hline & Cricket frass & $\begin{array}{l}\text { Fertilizer, crop protection and } \\
\text { soil conditioner }\end{array}$ & $\begin{array}{l}\text { (Robin, 2016); (Halloran, } \\
\text { 2016); (Skrivervik, 2018) }\end{array}$ \\
\hline Palm weevil farm & $\begin{array}{l}\text { Roasted palm } \\
\text { weevil }\end{array}$ & Bayelsa Suya or Maggot meat & $\begin{array}{l}\text { (Medubar and Owen, } \\
\text { 2013); (Ovie, 2018) }\end{array}$ \\
\hline Silk worm production & Silk & $\begin{array}{l}\text { Silk Clothes, Furniture and } \\
\text { Interior decoration }\end{array}$ & $\begin{array}{l}\text { (Mondal et al,2007, ); } \\
\text { (Oluwayemis, 2015) }\end{array}$ \\
\hline \multirow{4}{*}{$\begin{array}{l}\text { Bee keeping (Sting and } \\
\text { stingless) }\end{array}$} & Bee & Pollinator & (Marieke et al, 2005) \\
\hline & Honey & Food and drug & (Marieke, et al. 2005) \\
\hline & Bee bread & Apitherapy & (Marieke et al, 2005) \\
\hline & Royal jelly & $\begin{array}{l}\text { Apitherapy, Additive in energy } \\
\text { drink and creams }\end{array}$ & (Marieke et al, 2005) \\
\hline $\begin{array}{l}\text { Black soldier fly larvae } \\
\text { and housefly Maggot }\end{array}$ & Lavae & Fish feed, poultry feed & (Makinde, 2015) \\
\hline $\begin{array}{l}\text { Rhynchophorus spp, } \\
\text { Tenebrio molitor, Apis } \\
\text { mellifera }\end{array}$ & Insect fat & Biodiesel & $\begin{array}{l}\text { (Manzano-Agugliaro et al, } \\
\text { 2012) }\end{array}$ \\
\hline $\begin{array}{l}\text { Lucilia sericata, Blister } \\
\text { beetle, } \\
\text { Bee, }\end{array}$ & Larva, adult & $\begin{array}{l}\text { Larvae therapy, Horney } \\
\text { treatment and Insect venom }\end{array}$ & $\begin{array}{l}\text { (Cherniack, 2010) } \\
\text { (Spandita et al,2015) }\end{array}$ \\
\hline
\end{tabular}

\section{Inhibiting Factors Affecting Edible Insect Entrepreneurs in Nigeria \\ 1.Inadequate Credit facilities}

Most entrepreneurs in Nigeria are not developing due to lack of credit. Commercial banks will prefer to provide loan opportunities to bigger and established companies than smaller businesses and start ups (Ayegbe, 2016). Since edible insects enterprises are not that pronounce in the country, getting fund to finance such business may need more persuasion than regular businesses. Therefore, there is needs for government through microfinance banking to assist small businesses through loans.

\section{Poor Education, Knowledge and Skills of people in edible insect farming}

Knowledge is source of strength(Ayegba, 2016). Most entrepreneurs lack basic information in the enterprise they venture into. A good understanding of requisite skills needed for the business remain a veritable tool towards the 
success of the business. Entrepreneurs venturing into edible insect business should seek information regarding the business before venturing into it.

\section{Exposure to Modern Technology}

The amount of technological development of any country determines the success of entrepreneurs. Nigeria is rising technologically and once technological apparatus are in place to encourage the big and the small entrepreneurs.

\section{Poor extension service}

extensions service close the gap between research outcomes and farmers or edible insect business. This gap can be reduce only through training and employing more competent and effective extension agents who then train the farmers and adopt best practices also from the farmers.

\section{Conclusion}

The constant growth in the Nigerian population requires a commensurate growth in food production. Therefore, all available resources must be harnessed to ensure food availability to feed the present and future generations. Entrepreneurship has been identified as a solution to the high rates of youth unemployment facing the country. Insect farming has been presented as a good protein alternative to the conventional meat sources in Nigeria. Aside this, its high nutritional quality qualifies it as a food and as a good supplement in animal feed. Insects have also been reared for their function in industries such as medicine, textile industry and cosmetics. Therefore, this research presents edible insect farming and product development as viable entrepreneurial ventures and potential employment opportunities in Nigeria.

\section{Reference}

Abanikannda, M. (2012). Nutrient digestibility and haematology of Nile tilapia (Oreochromis niloticus) fed with varying levels of locust (Locusta migratoria) meal. Abeokuta,Nigeria: Federal University of Agriculture, Abeokuta, Ogun State, July 2012.

Adeoye, O. T., Oyelowo, O. J., Adebisi-Fagbohungbe, T. A., \& Akinyemi, O. D. (2014). Eco-Diversity of Edible Insects of Nigeria and Its Impact on Food Security. Journal of Biology and Life Science, ISSN 215760762014, Vol. 5, No. 2,URL: http://dx.doi.org/10.5296/jbls.v5i2.6109.

Afam, I., \& Netshiheni, R. K. (October 4th, 2017). Selected Edible Insects and Their Products in Traditional Medicine, Food and Pharmaceutical Industries in Africa: Utilisation and Prospects. In H. Mikkola, Future Foods. ntechOpen, DOI: 10.5772/intechopen.68330. Available from:

https://www.intechopen.com/books/future-foods/selected-edible-insects-and-their-products-in-traditionalmedicine-food-and-pharmaceutical-industrie.

Agbidye, F., \& Nongo, N. (2009). Harvesting and processing techniques for the larvae ofthe Pallid Emperor moth, Cirina forda Westwood (Lepidoptera: Saturniidae), among the Tiv people of Benue State. Nigeria Journal of Resource forestry, wildlife and Environment, 1 (1):123-132.

Alamu, O. T., Amao, A. O., Nwokedi, C. I., Oke, O. A., \& Lawa, I. O. (2013). Diversity and nutritional status of edible insects in Nigeria: A review. International Journal of Biodiversity and Conservation, Vol. 5(4), pp. 215-222,doi: 10.5897/IJBC12.121.

Alebiosu, I. B., Olatunde, G. O., \& Pitan, O. O. (2014). Developmental parameters and cocoon production by fivesilkworm, Bombyx mori L. (Lepidoptera: Bombicidae) hybrids at different feeding regimes. International Journal of Applied Agricultural and Apicultural Research, 10 (1\&2): 129-139.

Alegbeleye, W., Obasa, S., Olude, O., Otubu, K., \& Jimoh, W. (2012). Prelimi-nary evaluation of the nutritive value of the variegated grasshopper (Zonocerus variegatus L.) for African catfish Clarias gariepinus (Burchell. 1822) fingerlings . Aquaculture Resurces , 43:412-420.

Amobi, M., \& Ebenebe, C. (2018). Performance of boiler chicks fed on two insect based- diets in South East Nigeria. Journal of insect for food and feed , 4(4)- pp: 263-268.

Ande, A. T., \& Fasoranti, J. O. (1998). Some aspects of the biology, foraging and defensive behaviour of the emperor moth caterpillar, Cirina forda (Westwood). International Journal of Tropical Insect Science, 18(03), 177-181. doi:10.1017/s174275840002337.

Aniebo, A., Erondu, E., \& Owen, O. (2009). Replacement of fish meal with maggot meal in African catfish (Clarias gariepinus) diets. Revista Cientifica UDO Agricola , 9:666-671.

Awoniyi, T., Aletor, V., \& Aina, J. (2003). Performance of broiler- chickens fed on maggot meal in place of fishmeal. Int. J. Poult.Sci. . , 2: 271-274.

Ayegba, O. (2016). A Study on Factors Affecting Entrepreneurial Development in Nigeria. European Journal of Business and Management, Vol.8, No.12,

Ayieko, M., Ogola, H., \& Ayieko, I. (2016). Introducing rearing crickets (gryllids) at household levels: adoption, processing and nutritional values. Journal of Insects as Food and Feed , 2(3): 203-211DOI 10.3920/JIFF2015.0080. 
Bamgbose, A. ( 1999). Utilization of maggot-meal in cockerel diets. Indian J. Anim. Sci.. , 69: 1056-1058.

Banjo, A., Lawall, O. A., \& Songonuga, E. A. (2006). The nutritional value of fourteen species of edible insects in southwestern Nigeria. African Journal of Biotechnology, Vol. 5 (3), pp. 298-301, DOI: 10.5897/AJB05.250.

Bosch, G., Zhang, S., Oonincx, D. G., \& Hendriks., W. H. (2014). protein quality of insects as potential ingredients for dog and cat foods*. journal of nutritional science, vol. 3, e29, page 1 of 4,doi:10.1017/jns.2014.23.

Cherniack, P. E. (2010). Bugs as drug, Part 1: Insect. The new alternative medicine for the 21st century? Alternative Medicine review, Volume 15,Number 2.

Denisha, R., \& Rokozeno, M. D. (2016). Insect-Based Medicines: A Review of Present Status and Prospects of Entomo-Therapeutic Resources for Human Ailment. International Journal of Agriculture, Environment and Biotechnology, 9(6): 1069-1079, 10.5958/2230-732X.2016.00135.2.

Dicke, M. (2018). Insects as feed and the Sustainable Development Goals. Journal of Insects as Food and Feed, 4 (3) - Pages: 147 - 156, https://doi.org/10.3920/JIFF2018.0003.

Dobermann, A., Swift, J., \& Field, L. M. (2017). Opportunities and hurdles of edible insects for food and feed. Nutritional Bulletin, Volume42, Issue4, Pages 293-308, https://doi.org/10.1111/nbu.12291.

Ebenebe, C. I., \& Okpoko, V. O. ( 2016). Preliminary studies on alternative substrate for multiplication of African palm weevil under captive management. . Journal of Insects as Food and Feed , 2(3),171-177. doi:10.3920/jiff2015.0089 .

Ebenebe, C. I., \& Okpoko, V. O. (2015). Edible Insect Consumption in the South Eastern, Nigeria. International Journal of Scientific \& Engineering Research, Volume 6, Issue 6, June-2015 1459.

Ebenebe, C. (2005). Optimising Rearing condition of the grasscutter(Thryonomys swinderianus Temminck) in captive management. PHD thesis. Awka,Nigeria.: Nnamdi Azikwe university.

Ebenebe, C., Ameobi, M., Udegbala, C., Ufele, A., \& Nwaze, B. (2017). Survey of edible insect consumption in south eastern Nigeria. Journal insect as food and feed, Vol: 3(4): 241-251.

Ebenso, I., \& Udo, M. (2003). Effect of live maggot on growth of the Nile perch, Oreochromis niloticus (Cichlidae) in South Eastern Nigeria. Global J. Agric. Sci. , 2:72-73.

Francesco, L. B., Klaus, G. G., Mario, A., \& Verneau, F. (2017). Understanding Westerners' disgust for the eating of insects: The role of food neophobia and implicit associations. Food Quality and Preference , 64:120125,DOI: $10.1016 /$ j.foodqual.2017.10.002.

Gahukar, R. T. (2016). Edible Insects Farming: Efficiency and Impact on Family Livelihood, Food Security, and Environment Compared With Livestock and Crops. Insects as Sustainable Food Ingredients , 85-111. doi:10.1016/b978-0-12-802856-8.00004-1

GHOSH, S., HALDAR, P., \& MANDAL, D. K. (2014). Suitable food plants for mass rearing of the short-horn grasshopper Oxya hyla hyla (Orthoptera: Acrididae). Eur. J. Entomol , 111(3): 448-452, 2014.

Halloran, A. '. (2016). 'Life cycle assessment of edible insects for food protein: A review. Agronomy for Sustainable Development, 36(4),pp. 1-13. doi: 10.1007/s13593-016-0392-8.

Halloran, A., Roos, N., \& Hanboonsong, Y. (2016). Cricket farming as a livelihood strategy in Thailand. The Geographical Journal, , 183(1), 112-124. doi:10.1111/geoj.12184, Wiley pub.

Harinde, M., Gilles, T., Valérie, H., \& Philippe, A. (2014). State-of-the-art on use of insects as animal feed. Animal Feed Science and Technology, 197(2014)1-33.DOI: 10.1016/j.anifeedsci.2014.07.008.

Huis, A. V. (2003). Insects as Food in Sub-Saharan Africa. International Journal of Tropical Insect Science, Vol. 23, No. 3, pp. 163-185, DOI: 10.1017/S1742758400023572.

Huis, A. V., \& Oonincx, D. G. (2017). The environmental sustainability of insects as food and feed. A review. Agronomy for Sustainable Development, pp 37:43, DOI 10.1007/s13593-017-0452-8.

Huis, A. v., Itterbeeck, J. V., Klunder, H., Mertens, E., Halloran, A., Muir, G., et al. (2013). Edible insects:future prospects for food and feed security. FAO, Forst Report .

Huis, Arnold van. (2015). Edible insects contributing to food security. Agriculture and food security, Vol. 4:20, DOI 10.1186/s40066-015-0041-5.

Ihugba, O. A., Odii, A., \& Njoku, A. C. (2013). Challenges and Prospects of Entrepreneurship in Nigeria. Academic Journal of Interdisciplinary Studies, Vol 2 No 5.

Jakob, P. (2012, April 23). The Resource Curse in Nigeria A Story of Oil and Corruption. Financial Times, Special Report, p. 13.

James, \& Ketty. (2018, september 8). An Introduction to Cricket Flour and Reasons on why it's so Expensive. Retrieved february 11, 2019, from cowboy crickets website: https://www.cowboycrickets.com/blog/2018/9/8/an-introduction-to-cricket-flour-and-reasons-on-why-itsso-expensive

Kanika, T., Sangappa, S., Nirma, 1. K., \& Bindroo, B. B. (2016). Production of Pink Colored Silk Fabric Dyed Using a "Green" Dye-Fed Silkworm Approach. Aatcc Review , 16(1):48-57,DOI: 10.14504/ar.16.1.3.

Karigidi, M. (2018, April 17). Insects as sustainable sources of poultry feeds. Financial Nigeria, pp. 
http://www.financialnigeria.com/insects-as-sustainable-sources-of-poultry-feeds-blog-344.html.

Kenis, M., Koné, N., Chrysostome, C., Devic, E., Koko, G., Clottey, V., et al. (2014). Insects used for animal feed in West Africa. Entomologia, volume 2:218,DOI: 10.4081/entomologia.2014.218.

Kenis, M., Koné, N., Chrysostome, C., Devic, E., Koko, G., Clottey, V., et al. (2014). Insects used for animal feed in West Africa. Entomologia, 2:218.DOI: 10.4081/entomologia.2014.218.

Khalaf, A. A., \& Elansary, A. (2018). On the Nutritional Value of Edible Insects. Novel Techniques in Nutrition and food science, Volume 2 - Issue - 1.

Mähler, A. (2010, january 25). SSRN. Retrieved february 7, 2019, from http://ssrn.com/abstract=1541940.

Makinde, O. J. (2015). Maggot Meal: A Sustainable Protein Source for Livestock Production-A Review . Advances in Life Science and Technology, vol 31.

Manzano-Agugliaro, F., Sanchez-Muros, M. J., Barroso, F. G., Martínez-Sánchez, A., Rojo, S., \& Pérez-Bañón, C. ( (2012)). Insects for biodiesel production. . Renewable and Sustainable Energy Reviews , 16(6), 37443753. doi:10.1016/j.rser.2012.03.017

Marieke, M., Henk, V. B., Leen, V., Jaap, K., \& Jan, V. (2005). Bee products, properties, processing and marketing. Netherlands: Digigrafi, Wageningen,.

Medubar, i. B., P., V. K., \& Owen, O. J. (2013). Palm Weevil Larva (Rhynchophorus ferrugineus) Consumption as Supplement of Human Protein in the Diets of Inhabitants of Bayelsa State, Nigeria. International Journal of Health and Medical Information, , Volume 2, Number 1, .

Meludu, N. T., \& Onoja, M. N. (2018). Determinants of edible insects consumption level in Kogi State, Nigeria. Journal of Agricultural Extension , 22(1), 156. doi:10.4314/jae.v22i1.14.

Metu, A. G., \& Nwokoye, E. S. (2014). Entrepreneurship Development in Nigeria: Prospects and Challenges. International Conference on Entrepreneurship: Strategy for Socio-Economic (pp. 1-14). Iwo: Department of Business Administration, Faculty of Social and Management Sciences, Bowen University.

Miech, P., Lindberg, J., Berggren, A., Chhay, T., Khieu, B., \& A., J. (2016). Growth and survival of reared Cambodian field crickets (Teleogryllus testaceus) fed weeds and agricultural and food industry byproductsindustry by-products. . Journal of Insects as Food and Feed , : 2 (4), 285-292.

Mondal, M., Trivedy, K., \& K., N. (2007, ). The silk proteins, sericin and fibroin in silkworm,Bombyx mori Linn., - a review. Caspian J. Env. Sci. , Vol. 5 No. 2 pp. 63 76.

Muafor, F. J., Gnetegha, A. A., Philippe, L. G., \& Patrice, L. (2015. ). Exploitation, trade and farmingof palm weevil grubs in Cameroon. . Working Paper, 178. Bogor, Indonesia: CIFOR.

Nawaz, A., Mohib, B., \& Asad, L. (2012). Effect of Product Packaging in Consumer Buying Decision. Journal of Business Strategies, Vol.6, No. 2, pp 1-10

Niels, H. J., \& Lieberoth, A. (2018). We will eat disgusting foods together - Evidence of the normative basis of Western entomophagy-disgust from an insect tasting. Food Quality and Preference, DOI: 10.1016/j.foodqual.2018.08.012.

Ogunji, J., Kloas, W., Wirth, M., Neumann, N., \& Pietsch, C. (2008). Effect of housefly maggot meal (magmeal) diets on the performance, concentration of plasma glucose, cortisol and blood characteristics of Oreochromis niloticus fin-gerlings. . J. Anim. Physiol. Anim. Nutr, 92:511-518.

Ojewola, G., Eburuaja, A., Okoye, F., Lawal, A.S., \& Akinmutimia, H. (2003). Effect of inclusion of grasshopper meal on perform-ance, nutrient utilization and organ of broiler chicken. J. Sustain.Agric. Environ, 5: 19-25 .

Okore, O., Avaoja, D., \& Nwana, I. (2014). Edible Insects of the Niger Delta Area in Nigeria. . Journal of Natural Sciences Research, Vol. 4 (5): 1-9. www.iiste.org.

Oluokun, J. (2000). Upgrading the nutritive value of full-fat soyabeanmeal for broiler production with either fishmeal or black soldier flylarvae meal (Hermetia illucens). Nigerian J. Anim. Sci. , 1: 51-61.

Oluwayemis, i. G. (2015). Profitability of Cocoon Production in Ado-Ekiti, Ekiti State, Nigeria. Journal of Agricultural Science, Vol. 7, No. 9.

Ovie, F. Z. (2018, july 27). BodmasNews. Retrieved February 11, 2019, from BENEFITS OF EATING INSECTS (ENTOMOPHAGY) A CASE STUDY OF (BAYELSA STATE): https://www.bodmasnewsblog.com/whyit-is-good-to-eat-the-insect-known-as-bayelsa-suya/

Oyegoke, O., Akintola, A., \& Fasoranti, J. (2006). Dietary poten-tials of the edible larvae of Cirina forda(westwood) as a poultryfeed. Afr. J. Biotechnol. , 5:1799-1802.

Robin, N. (2016, 08 28). Gardens and green house. Retrieved february 11, 2019, from Natural Cricket Frass Fertilizer 4-2-2: https://www.gardenandgreenhouse.net/products/natural-cricket-frass-fertilizer-4-2-2/

Sharah, H. A. (2013). Profitability drive against risk: the case of grasshopper collection business in Maiduguri, a semi-arid zone of north-eastern Nigeria. International Journal of Agricultural Sciences, Vol. 3 (1), pp. 373378 ,

Skrivervik, E. (2018). The Bioeconomy and Food Waste:. TIK WORKING PAPERS , https://www.sv.uio.no/tik/InnoWP/tik_working_paper_20181021.pdf.

Spandita, R., Sumana, S., \& Partha, P. (2015). Insect natural products as potential source for alternative medicines 
- A Review. World Scientific News , 19 (2015) 80-94.

Tiencheu, B., \& Womeni, H. (2017). Entomophagy: Insects as Food. In Insect Physiology and Ecology (pp. Chapter: 10, pp 234-253). InTechOpen.

Veldkamp, T., \& Bosch, G. (2015). Insects: a protein-rich feed ingredient in pig and poultry diets. Animal frontier , vol 5, No. 2,DOI: 10.2527/af.2015-0019. 